\title{
Development of Bioavailability Enhancement System for the Skin Permeation Promotion of Psolarea corylifolia Extract
}

\author{
Young Ho Cho ${ }^{1}$, Ghe Whan $\mathrm{Ahn}^{2}$, Seung Won Yang ${ }^{2}$, Kwan Hyun $\mathrm{Cho}^{2}$, Sang Won Kim ${ }^{2}$, Ki Myoung Baek ${ }^{1}$, \\ and Gye Won Lee ${ }^{1 *}$
}

접수: 2011년 10월 14일 / 게재승인: 2011년 11월 29일

(C) 2011 The Korean Society for Biotechnology and Bioengineering

\begin{abstract}
Psolarea corylifolia extract that contains bakuchiol is known to have anti-microbial, anti-inflammatory and anti-scarring effects. In this study, a vesicles such as liposome, niosome, and transfersome were produced to encapsulate P. corylifolia extract and measured their stability and physiochemical property. The skin permeation and partitioning of $P$. corylifolia extract in the vesicles were elucidated in nude mouse skin by using Franz diffusion cells after topical application for $24 \mathrm{~h}$. After storage at $25,40,70^{\circ} \mathrm{C}$, and light, the stability of bakuchiol incorporated into the vesicles was maintained for 30 days. The optimal concentration of $P$. corylifolia extract entrapped into the vesicles was found to be $5 \sim 10 \%$. From the physicochemical studies, after storage at 4,25 , and $40^{\circ} \mathrm{C}$, the viscosity and particle size of the vesicles remained in $30 \sim 80 \mathrm{cP}$ and the nanosize range for 6 months, respectively. From the permeation experiments, niosome showed a higher amount of bakuchiol permeated through the mouse skin compared to liposome and transfersome after $24 \mathrm{~h}$. From these results, niosome and transfersome could be a good bioavailability enhancement system (BAES) for $P$. corylifolia extract to improve the skin permeation and

\footnotetext{
${ }^{1}$ 건양대학교 제약공학과 제제 개발실

${ }^{1}$ Laboratory of Galenic Technology, Department of Pharmaceutical Engineering, Konyang University, Nonsan 320-711, Korea

Tel: +82-41-730-5692, Fax: +82-41-735-9117

2 (주)남양

${ }^{2}$ Namyang Inc., Chungbuk 365-850, Korea
}

e-mail: pckmon@konyang.ac.kr
\end{abstract}

stability.

Keywords: Psolarea corylifolia extract, bioavailability enhancement system, skin permeation, skin deposition

\section{1. 서론}

경제성장, 외모에 대한 관심의 증가, 환경오염에 인한 복합 적인 요인으로 피부 트러블에 대한 관심이 증가하고 소비자 들의 트러블 제품에 대한 소비가 늘어나고 있다. 또, 제품 의 효능과 효과에 대한 소비자들의 적극적인 조사와 요구에 의해 일반 화장품에 비해 높은 수준의 제품을 원하고 화장 품 업계에서도 뛰어난 소재에서 나아가 소재를 안정하고 효 능 효과를 증진할 수 있는 차별화된 기술을 접목 하려고 시도하고 있다. 기능 성분과 제형의 고유특성에 따라 붕해 (disintegration), 용해 (dissolution), 투과 (permeability) 특성 에 영향을 미치는 변동인자를 조절하여 인체 내 흡수율을 높여 생체 이용률을 증가시키는 한편 열, 빛, 산화 안정성은 물론 천연 성분의 독특한 맛의 마스킹을 통하여 소비자의 다양한 요구에 부합되는 제품 개발기술이 필요하다. 이 중 BAES (bioavailability enhancement system)는 “생체 이용 률 촉진 시스템" 으로 천연물의 주요 효능, 효과를 부가 시키 려는 독창적인 제제화 기술의 일종으로서 화장품 분야에서 사용되는 용어이다 [1].

생체 이용율 촉진 시스템 중의 하나인 liposome은 피부 투과뿐만 아니라 물, 산소, 빛 등에 의해 쉽게 산화되는 불안 정한 물질을 안정화시키고 liposome에 포집된 물질의 방출 
속도를 필요에 따라 조절하는 기능으로 인하여 의약, 화장품, 식품 등에 널리 이용되어 왔으나 [2-5] 산화적 분해가 일어나 기 쉽고 고가이며 정제가 어려운 단점이 있다 [6,7].

이러한 liposome의 단점을 보완하고 피부 투과율을 높 이기 위해 기존의 liposome을 변형한 새로운 형태의 vesicles 개발이 이어졌는데 vesicles 막이 겔 상태보다 liquid 상태 에서의 피부 각질층을 더욱 잘 투과할 수 있는 점을 고려해 서 더 유연하면서 탄력적으로 변형이 쉬운 상태의 vesicles 을 만들려는 시도가 이루어졌다 [8-11]. 그 예로 niosome, transfersome, deformal liposome, ethosome 등이 개발되었다.

Niosome은 세라마이드, 세레브로마이드, 스핑고마이엘린 등의 스핑고리피드 유도체를 사용하여 vesicles을 형성하면서 활성 성분을 안정하게 봉입할 수 있을 뿐만 아니라 liposome 의 다양한 순도의 인지질 및 높은 비용, 화학적 불안정성과 같은 문제점을 해결할 수 있는 것으로 보고되고 있다 $[9,12]$.

Transfersome은 기존의 liposome에 일명 edge activator 라고 일컬어지는 sodium cholate와 같은 계면활성제나 lysophosphatidyl choline과 같은 단일 사슬 인지질을 적당한 양으로 혼합하여 만들어지는데 이 경우 transfersome은 극단 적 변형 (ultradeformation)이 가능하여 각질층의 아주 작은 틈 사이로 침투 이동이 더욱 효과적으로 이루어지는 것으로 보고되고 있다 $[13,14]$.

보골지는 1년생 초본식물인 파고지 (Psoralea corylifolia L.)의 성숙한 종자로 주요 작용 성분은 방향족 고리상의 단 일 하이드록실기 및 불포화 탄화수소 사슬을 가지는 페놀성 화합물인 바쿠치올 (Fig. 1)로 알려져 있다. 이 성분은 항암, 항산화 및 간 보호 활성 작용을 가질 뿐만 아니라 구강내 병원균에 대한 항균효과 때문에 충치 예방과 치료를 위해 식품 첨가물 및 가글제로의 개발 가능성이 큰 것으로 보고되 어 왔다 [15-17]. 또한, 바쿠치올은 여러 가지 질병 예방 및 치료에 사용하기 위한 생물학적 활성을 가지는 천연물로서 화장품 분야에서도 여드름 및 아토피 치료제의 가능성이 검토 되어 최근 여드름 치료에 탁월한 효과를 얻은 바 있다 [18]. 반면에 바쿠치올은 여러 가지 우수한 효능을 나타내지만 빛 과 열에 의한 안정성이 떨어지는 등의 문제점이 있는 것으 로 알려져 있다.

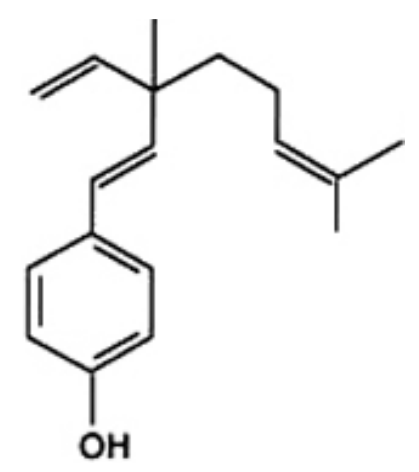

Fig. 1. Structure of bakuchiol from Psoralea coryfolia extract.

따라서 본 연구에서는 상기의 문제점을 보완하고 여러 가 지 효능으로 주목받고 있는 바쿠치올을 함유하는 보골지 추
출물의 피부 적용 가능성을 알아보기 위하여 보골지 추출물 을 liposome, niosome 및 transfersome과 같은 생체 이용률 촉진 시스템 $(\mathrm{BAES})$ 에 적용하여 이들의 안정성을 평가하고 피부 투과에 미치는 영향을 평가하였다.

\section{2. 재료 및 방법}

\section{1. 기기 및 시약}

시약으로는 보골지 추출물 (Psoralea coryfolia extract)을 Unigene사 (Chunan, Korea)에서, HPLC용 아세토니트릴 과 메탄올을 JT Baker사 (Austin, USA)에서, lipoid S $75-3^{\circledR}$ 는 Lipoid사 (Ludwigshafen, Germany)에서, S-570 ${ }^{\circledR}$ 은 Mitsubishi-Kagaku Foods Co.사 (Tokyo, Japan)에서, cholesterol, caprylic/capric triglyceride 및 macadamia ternifolia seed oil은 Croda Ins.사 (NJ, USA)에서, Amphisol ${ }^{\mathbb{B}}$ 은 DSM사 (JH Heerlen, Netherlands)에서, lysolecithin은 Lucas Meyer Cosmetics사 (Champlan, France)에서 glycerine 과 methyl pyrrolidone은 Lipo Chemicals Inc.사 (NJ, USA) 에서, Brassica campestris (rapeseed) sterol과 PEG-5 rapeseed sterol은 Cognis사 (Duesseldorf, Germany)에서 그리고 ceteth-3과 5는 Nihon emulsion사 (Tokyo, Japan) 에서 각각 구입하여 사용하였으며, 그 외의 시약과 용매는 특급 또는 1 급을 사용하였다.

기기로는 magnetic stirrer \& hot plate (Yhana Ins., Seoul, Korea), centrifuge (Hanil Science Industrial, Incheon, Korea), Franz diffusion cell (Labfine, Seoul, Korea), Ultra-Turrax homogenizer (IKA Inc., Werke, Germany), vortex mixer (Scientific Industries Inc., PA, USA), HPLC (Waters, MA, USA) 및 sonicator (Kodo Technical Research Co., Hwaseong, Korea), $\mathrm{pH}$ meter (Thermo Electronic Company Inc., NJ, USA), rheometer (Brookfield, MA, USA), Transmission electron microscopy (Hitachi LTD, Tokyo, Japan), 마이크 로 플루다이저 (Microfluidics, MA, USA) 및 항온항습기 (Joeil Science, Seoul, Korea)를 사용하였다.

\section{2. 보골지 추출물 (바쿠치올)의 안정성}

보골지 추출물을 함유하는 liposome, niosome 및 transfersome 을 제조할 때 빛과 온도에 영향을 받는지 확인하기 위하여 바쿠치올의 함량 변화를 측정하는 안정성 실험을 실시하였 다. 즉, $5 \%$ 의 보골지 추출물을 함유하도록 제조 방법에 따라 liposome, niosome 및 transfersome을 제조하여 실온, 40 및 $70^{\circ} \mathrm{C}$ 에서 각각 30 일 동안 보관하면서 $0,7,15$ 및 30 일 마다 검체를 취하여 바쿠치올의 함량 변화를 측정하였다.

\subsection{HPLC 분석 조건}

보골지 추출물의 여러 가지 성분 중에서 바쿠치올을 지표물 질로 사용하여 분석하였다. 분석조건으로는 컬럼은 phenylhexyl을, 온도는 $35^{\circ} \mathrm{C}$, 유속은 $1.0 \mathrm{~mL} / \mathrm{min}$ 으로, detection은 $260 \mathrm{~nm}$ 에서 검체량은 $20 \mu \mathrm{L}$ 를 주입하여 Table 1 의 이동상 조건으로 분석하였다. 
Table 1. Condition of mobile phase to isolate bakuchiol from extracts of Psoralea corylifolia L.

\begin{tabular}{ccc}
\hline Time $(\min )$ & Water & Acetonitrile \\
\hline 0 & 64 & 36 \\
8 & 64 & 36 \\
20 & 0 & 100 \\
23 & 0 & 100 \\
28 & 64 & 36 \\
31 & 64 & 36 \\
\hline
\end{tabular}

2.4. 보골지 추출물을 함유하는 Vesicles (niosome, liposome 및 transfersome)의 제조 및 Characterization

\subsection{1. 보골지 추출물을 함유하는 vesicles 의 제조}

한방 생약 성분류는 주요 성분 이외에도 사포닌, 배당체의 일종인 탄닌, 플라보노이드, 카로티노이드 및 그 밖에 단당 류, 다당류, 다당류 섬유질, 아미노산, 단백질, 비타민류, 미 네랄 등과 기타 미확인 물질이 많이 존재하므로 화장품에의 적용시 사용 함량과 원료 선택 및 제품의 안정성 확보면에서 문제점이 있었으며, 또한 한방 생약 성분류는 오랜 임상경 험을 통해 안정성은 인정되었으나 고유의 약리 작용은 완만 하여 빠른 효과를 얻기 어렵다는 문제가 있었다. 따라서 기존 의 방법으로는 미용 성분의 방출 및 침투가 순간적으로 이루 어져 피부 활성 성분의 고유 기능 및 효과를 충분히 발휘 할 수 없다는 문제점이 제기되므로 이를 해결하기 위해서는 피부 각질층의 세포간 지질성분과 유사한 세라마이드, 시토 스테롤, 콜레스테롤을 이용하여 미세다중 소구체화 함으로써 함유된 피부활성 성분의 본래의 기능 및 효과를 증진시키는 동시에 성분 보존력을 향상시켜 보다 안정한 상태로 유지될 수 있다는 것으로 알려져 있다 [19,20].

본 연구에서도 보골지 추출물을 함유하는 niosome, liposome 및 transfersome을 Table 2와 같은 조성에 따라 특허의 방법을 약간 변형하여 제조하였다.

Table 2. Formulations of vesicles (niosome, liposome, and transfersome) containing $P$. coryfolia extract

\begin{tabular}{|c|c|c|c|}
\hline \multirow{2}{*}{ Ingredients } & \multicolumn{3}{|c|}{ Vehicle $(\mathrm{w} / \mathrm{w} \%)$} \\
\hline & Niosome & Liposome & Transfersome \\
\hline Caprylic/Capric Triglyceride & 10 & - & - \\
\hline Macadamia ternifolia Seed Oil & 5 & - & - \\
\hline Brassica campestris (Rapeseed) Sterol & 3 & - & - \\
\hline PEG-5 Rapeseed Sterol & 3 & - & - \\
\hline Ceteth-3 & 2 & - & - \\
\hline Ceteth-5 & 2 & - & - \\
\hline Lipoid S 75-3 ${ }^{\circledR}$ & - & 5 & 3 \\
\hline $\mathrm{S}-570^{\circledR}$ & 1 & - & - \\
\hline Cholesterol & 3 & 0.5 & 0.5 \\
\hline Amphisol $^{\circledR}$ & 0.6 & 0.6 & 0.6 \\
\hline Lysolecithin & - & - & 0.5 \\
\hline Ethanol & - & 10 & 10 \\
\hline Glycerine & 4 & 6 & 4 \\
\hline Psoralea coryfolial extract & 5 & 5 & 5 \\
\hline Methyl pyrrolidone & 5 & 5 & 5 \\
\hline Water & \multicolumn{3}{|c|}{ qs to 100} \\
\hline
\end{tabular}

Niosome은 고형 지질을 $95 \sim 105^{\circ} \mathrm{C}$ 에서 용해한 후, 수상 을 넣어 충분히 팽윤하고 마이크로플루다이저 $\left(70 \sim 75^{\circ} \mathrm{C}\right.$, $1000 \mathrm{bar}$ )를 1 회 통과시켜 1차 분산액을 제조하였다. 여기 에 보골지 추출물을 넣고 마이크로플루다이저 $\left(40 \sim 45^{\circ} \mathrm{C}\right.$, $1000 \mathrm{bar})$ 를 2회 통과시킨 후 실온으로 냉각하여 균일한 niosome 현탁액을 얻었다 (Scheme 1).

\begin{tabular}{|c|c|}
\hline \multicolumn{2}{|c|}{ Dissolving lipid phase } \\
\hline & $\begin{array}{l}95 \sim 105^{\circ} \mathrm{C} \\
\leftarrow \text { Adding aqueous phase }\end{array}$ \\
\hline \multicolumn{2}{|c|}{ Swelling } \\
\hline \multicolumn{2}{|c|}{ Microfludizer cycling $\left(1,000 \mathrm{bar}, 70 \sim 75^{\circ} \mathrm{C}, \times 1\right)$} \\
\hline & $\begin{array}{l}\leftarrow \text { Adding P. coryfolia extract } \\
\quad\left(5 \mathrm{~min}, 50 \sim 55^{\circ} \mathrm{C}\right)\end{array}$ \\
\hline \multicolumn{2}{|c|}{ Microfludizer cycling $\left(1,000 \mathrm{bar}, 45 \sim 50^{\circ} \mathrm{C}, \times 2\right)$} \\
\hline & Cooling \\
\hline Niosom & suspension \\
\hline
\end{tabular}

Scheme 1. Preparation procedure of niosome containing $P$. coryfolia extract.

liposome과 transfersome은 수상과 유상을 혼합한 후에 $59 \sim 61{ }^{\circ} \mathrm{C}$ 에서 5 분간 $3,600 \mathrm{rpm}$ 으로 유화 시킨 후, 마이크 로플루다이저 $\left(45 \sim 50^{\circ} \mathrm{C}, 1000 \mathrm{bar}\right)$ 를 3 회 통과시켰다. 여기 에 보골지 추출물을 첨가하고, 다시 $1,000 \mathrm{bar}$ 의 조건으로 마이크로플루다이저를 1회 더 통과시켜 균일한 liposome, transfersome 현탁액을 얻었다 (Scheme 2).

\begin{tabular}{|c|c|}
\hline \multicolumn{2}{|c|}{ Mixing aqueous and lipid phase } \\
\hline & $\begin{array}{l}\leftarrow \text { Emusification } \\
\left(5 \mathrm{~min}, 59 \sim 611^{\circ} \mathrm{C}\right)\end{array}$ \\
\hline \multicolumn{2}{|c|}{ 1st emulsion } \\
\hline \multicolumn{2}{|c|}{ Microfludizer cycling $\left(1,000 \mathrm{bar}, 45 \sim 50^{\circ} \mathrm{C}, \times 3\right)$} \\
\hline & $\begin{array}{l}\leftarrow \text { Adding } P \text {. coryfolia extract } \\
\left(5 \mathrm{~min}, 39 \sim 41^{\circ} \mathrm{C}\right)\end{array}$ \\
\hline \multicolumn{2}{|c|}{ Microfludizer cycling $\left(1,000 \mathrm{bar}, 39 \sim 41^{\circ} \mathrm{C}, \times 1\right)$} \\
\hline & Cooling \\
\hline Liposome / Trans & fersome suspension \\
\hline
\end{tabular}

Scheme 2. Preparation procedure of liposome/transfersome containing P. coryfolia extract.

\subsection{2. 최적 약물 농도의 결정}

Liposome, niosome 및 transfersome을 제조하여 안정한 상태를 유지하는 보골지 추출물의 농도를 결정하기 위하여 침전의 유무로 안정성을 관찰하였다.

\subsubsection{Vesicles 의 Morphology}

보골지 추출물이 함유된 liposome, niosome 및 transfersome 의 구조를 $\mathrm{TEM}$ 을 이용하여 측정하였다. 
(a)

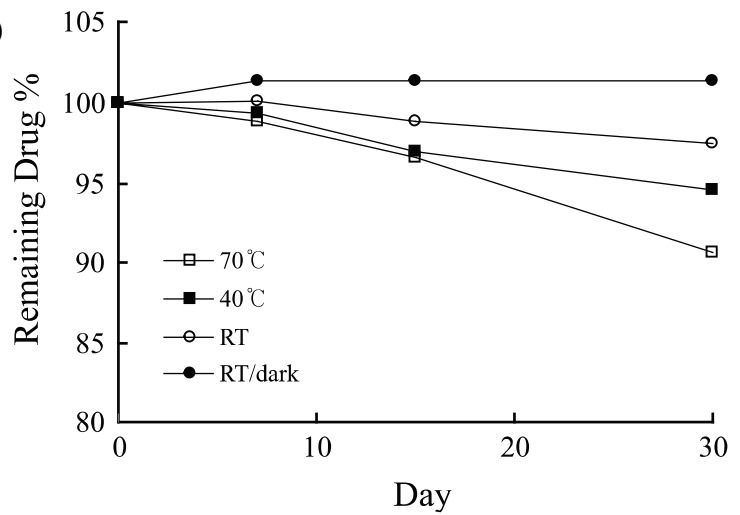

(c)

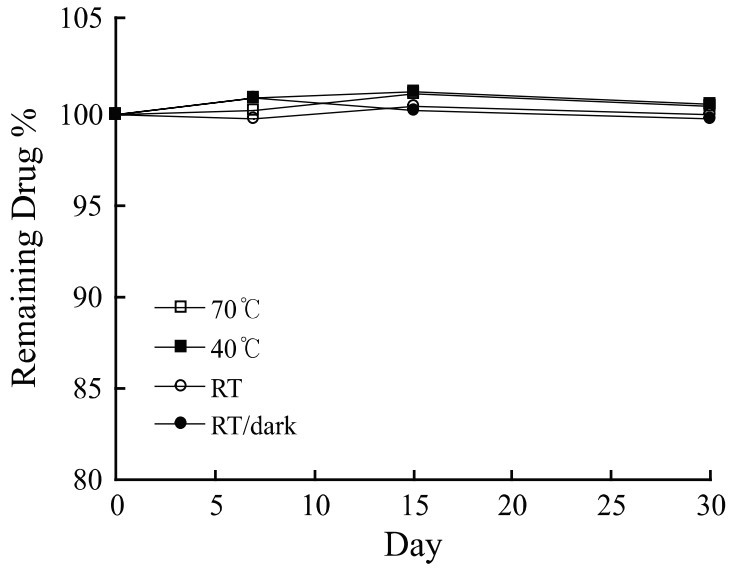

(b)

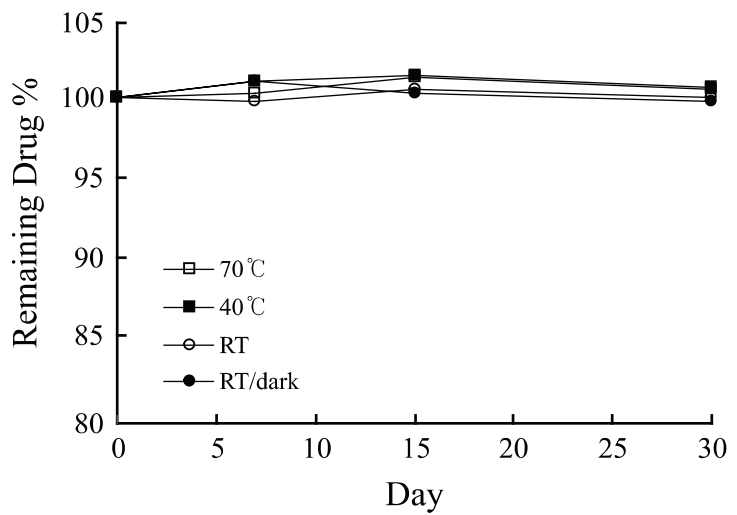

(d)

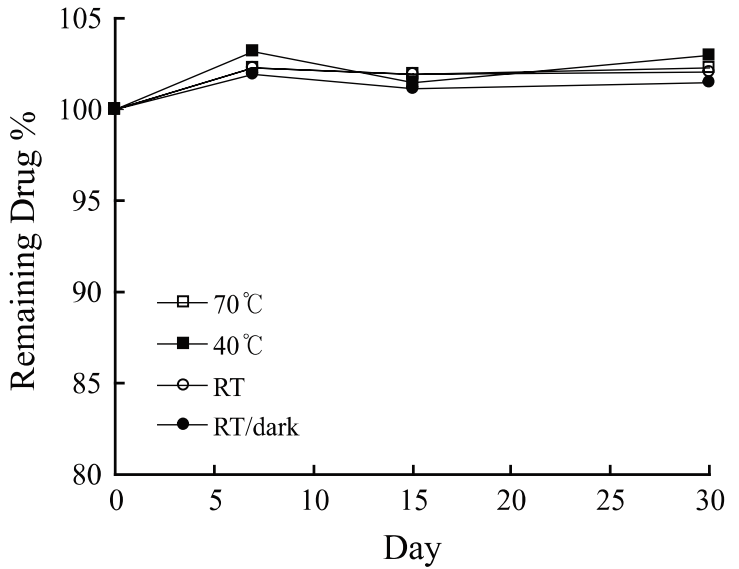

Fig. 2. The change of bakuchiol content in P. coryfolia extract (a), niosome (b), liposome (c), and transfersome (d) after storage for 30 days at 25,40 and $70^{\circ} \mathrm{C}$.

\subsection{Vesicles 분산액의 안정성}

제조된 liposome, niosome 및 transfersome 분산액의 안정성 시험은 6 개월 동안 $4^{\circ} \mathrm{C}$, 실온 $\left(25^{\circ} \mathrm{C}\right.$, 빛에 노출 $)$ 및 $40^{\circ} \mathrm{C}$ 에 6 개월간 보관하면서 0,3 및 6 개월 간격으로 검체를 취하여 점도, $\mathrm{pH}$ 및 성상의 변화를 측정하여 검토하였다. 이때 제조 된 liposome, niosome 및 transfersome 분산액의 평균 입자 크기는 동적 광산란 기법을 이용하여 측정하였다 [21-23]. 이때 광원으로 $\mathrm{He}-\mathrm{Ne}$ laser, 측정 파장은 $632.8 \mathrm{~nm}$, 산란각 도는 $90^{\circ}$ 로 설정하고 $25 \pm 1^{\circ} \mathrm{C}$, intensity $8000 \sim 14000 \mathrm{cps}$ 에 서 3 차 증류수로 10 배 희석하여 측정하였다.

\section{6. 피부 투과 및 침적 실험}

피부 투과 및 침적 실험에 사용된 마우스는 6주령의 웅성 누드 마우스로 다물 사이언스 (Daejeon, Korea)에서 구입 하여 $20 \sim 23^{\circ} \mathrm{C}$, 상대습도 $55 \pm 5 \%$, 명암 교대시간 12 시간을 유지하는 조건에서 실험 중을 제외하고는 먹이와 물을 충분 히 공급하여 1 주일간 적응시킨 후 사용하였다.

실험에 사용된 검체는 보골지 추출물 $5 \%$ 를 함유하는 niosome, liposome 및 transfersome 분산액을 각각 제조하여 사용하였다.

누드 마우스의 등 쪽 피부를 떼어내어 피하 지방과 조직 들을 생리식염수로 피부가 상하지 않도록 주의하여 제거한 다음 보관 과정 없이 즉시 실험에 사용하였다. 즉, 제조된 제제를 피부에 도포하여 Franz형 확산 셀을 사용하여 $37 \pm$ $0.5^{\circ} \mathrm{C}$ 로 유지시키면서 $600 \mathrm{rpm}$ 으로 교반하면서 실시하였다. 이때 제제를 투여한 피부의 면적은 $2.54 \mathrm{~cm}^{2}$ 이고, receptor phase는 인산염 등장 완충액 (pH 7.4) $12 \mathrm{~mL}$ 로 채웠다.

보골지 추출물을 포함한 vesicles $1 \mathrm{~g}$ 을 피부 표면에 도 포하고 $1,2,4,8,12$ 및 24시간마다 $0.2 \mathrm{~mL}$ 씩 채취하여 HPLC에 직접 주입하여 Table 1의 조건으로 분석하였다. 채취된 양은 즉시 동량의 인산염 등장 완충액 $(\mathrm{pH}$ 7.4)으로 보충하였다.

피부 투과실험의 마지막 채취 시간인 24시간 이후에 피부 표면, 각질 및 각질이 제거된 피부에 침적된 양을 다음과 같이 처리하여 측정하였다. 즉, 피부 표면에 남아있는 물질의 양은 메탄올로 씻어내어 제거하여 측정하였다. 또한, 피부에 침적된 양을 측정하기 전에 각질에 침적된 약물의 양을 알아 보기 위해 제제와 접촉하였던 피부 면적 $2.54 \mathrm{~cm}^{2}$ 을 취하여 cellophane adhesive tape을 20-30회 반복하여 붙였다 떼어 내어 각질층을 제거하여 이를 메탄올 또는 $70 \%$ 에탄올을 적 당량 넣어 90 분간 sonication하였다. 10 분간 원심분리 한 뒤 에 상층액을 취하여 여과한 후, 여액을 직접 HPLC로 정량 하여 각질층에 침적된 약물의 양을 정량하였다.

각질층이 제거된 피부를 해부용 가위를 사용하여 잘게 자른 뒤 $5 \sim 10 \mathrm{~mL}$ 의 메탄올 또는 $70 \%$ 에탄올을 첨가하여 5 분간 혼합한 후 하룻밤 방치하고 90 분간 sonication하였 다. $15,000 \mathrm{rpm}$ 으로 10 분간 원심분리 한 뒤에 상층액을 취 하여 여과한 후, 여액을 직접 HPLC로 정량하여 피부 내 침 
적된 약물의 양을 정량하였다.

\section{7. 통계학적 분석}

모든 결과는 평균 \pm 표준편차로 표시하였으며, 투과되거나 침적된 양의 통계처리는 SPSS 12.0 program을 사용하여 one-way ANOVA에서 유의한 F값의 항목을 Scheffe's test 를 이용하여 $\mathrm{p}<0.05$ 수준에서 유의성을 검정하였다.

\section{3. 결과 및 고찰}

\section{1. 보골지 추출물 (바쿠치올)의 안정성}

보골지 추출물을 30 일 동안 실온, $40^{\circ} \mathrm{C}$ 및 $70^{\circ} \mathrm{C}$ 에 각각 보관 하면서 빛과 열에 대한 바쿠치올의 안정성을 측정한 결과 제형화하지 않은 원료 자체에서는 빛과 열에 대해서 약간 불안정한 것으로 나타났다. 즉, 30 일 이후에 $40^{\circ} \mathrm{C}$ 와 $70^{\circ} \mathrm{C}$ 에 서 5 10\% 정도 분해되는 것을 확인하였다. 또한, 빛에 대해 서도 불안정하여 $3 \%$ 정도 분해되는 것을 확인하였다. 반면 에 liposome, niosome 및 transfersome으로 제형화할 때 열과 빛에 대한 안정성도 제제화의 중요한 인자라 할 수 있는데 보골지 추출물을 제제화하여 관찰한 결과 열과 빛에 대해서 아주 안정한 것으로 관찰되었다 (Fig. 2).

\section{2. 생체이용률 촉진시스템의 제조 및 Characterization 3.2.1. Vesicles 의 Morphology}

보골지 추출물을 함유하는 liposome, niosome 및 transfersome 을 제조한 후 TEM을 이용하여 형태를 관찰한 결과 vesicles 이 양호하게 형성된 것을 확인할 수 있었다 (Fig. 3). (a)

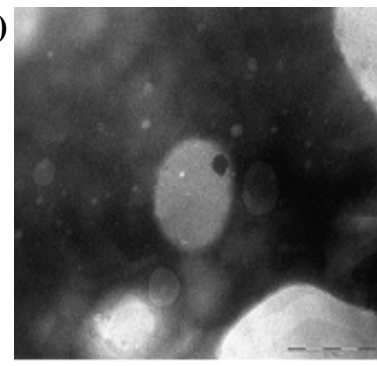

(c)

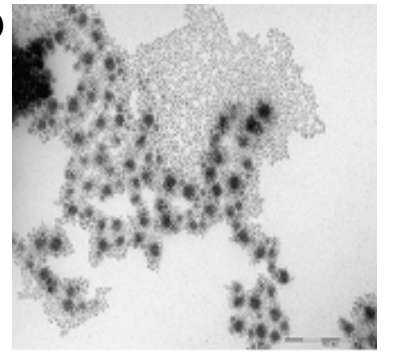

(b)

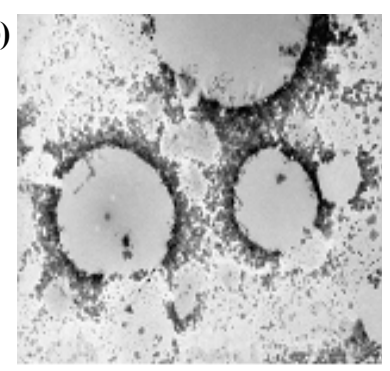

Fig. 3. The transmission electron microscopic images of niosome (a), liposome (b), and transfersome (c) containing P. coryfolia extract (x 1,000).

\subsection{2. 최적 약물 농도의 측정}

Liposome, niosome 및 transfersome을 제조하여 안정한 상태
를 유지하는 보골지 추출물의 농도를 결정하기 위하여 침전 의 유무로 안정성을 관찰하였다. 그 결과 응집이나 침강이 일어나지 않고 liposome, niosome 및 transfersome을 안정 하게 제조할 수 있는 보골지 추출물의 최대 농도는 각각 24 , 22 및 $27 \%$ 로 나타났으나, 보골지 추출물을 높게 함유하는 경우 48시간 이후 침강 등의 현상이 나타났다 (data not shown). 따라서 vesicles이 안정하게 유지되는 보골지 추출물의 농도 를 검토한 결과 세 가지 제형 모두 5 10\%의 범위가 최적인 것으로 나타났다. 따라서 실험에 사용된 보골지 추출물의 농 도는 임상 실험 결과 효능이 나타나기 시작한 바쿠치올의 농도 $0.5 \%$ 로 맞추어 주기 위하여 $5 \%$ 로 고정하여 vesicles을 제조하여 검체로 사용하였다.

\subsection{Vesicles의 안정성}

제조된 vesicles의 안정성을 측정하기 위하여 6 개월 동안 $4^{\circ} \mathrm{C}$, 실온 $\left(25^{\circ} \mathrm{C}\right)$ 및 $40^{\circ} \mathrm{C}$ 에서 보관하면서 0,3 및 6 개월 간격으로 검체를 취하여 점도, $\mathrm{pH}$, 성상의 변화 및 입자크 기를 측정한 결과 모든 vesicles은 안정한 것으로 나타났다.

즉, 보골지 추출물이 함유된 liposome, niosome 및 transfersome의 점도 변화를 측정한 결과 Fig. 4에 나타낸 바와 같이 liposome의 경우 $4^{\circ} \mathrm{C}$ 에서 제조 직후 $67.6 \pm 2.75$ 에서 3 개월 후 $87.2 \pm 2.75$ 로 증가되었다가 6 개월 후 $79.3 \pm$ 2.11 로 제조 직후 수준으로 회복되었다. 반면에 $40^{\circ} \mathrm{C}$ 에서 는 3 개월 후 $37.5 \pm 10.38$ 로 감소된 후 6 개월 후까지 지속 되었다. niosome의 경우 $4^{\circ} \mathrm{C}$ 에서 제조 직후 $48.2 \pm 12.87$ 에 서 3 개월 후 $95.9 \pm 4.97$ 로 증가되었다가 6 개월 후 $76.9 \pm$ 13.76로 감소되어 제조 직후 보다는 약간 상승한 상태로 유지되었다. $40^{\circ} \mathrm{C}$ 에서는 유의적인 변화는 관찰되지 않았다. transfersome의 경우 $4^{\circ} \mathrm{C}$ 에서 제조 직후 $52.9 \pm 9.09$ 에서 3 개월 후 $57.5 \pm 12.65$ 로 제조 직후와 비슷하게 유지되다가 6 개월 후 $74.3 \pm 6.72$ 로 약간 상승하는 것으로 나타났다. $40^{\circ} \mathrm{C}$ 에서는 niosome과 마찬가지로 유의적인 변화는 관찰 되지 않았다. 이러한 결과로 보아 liposome, niosome 및 transfersome의 점도는 모든 보관 조건에서 6개월 동안 30 $90 \mathrm{cP}$ 사이에서 점도가 유지되는 것으로 나타났다.

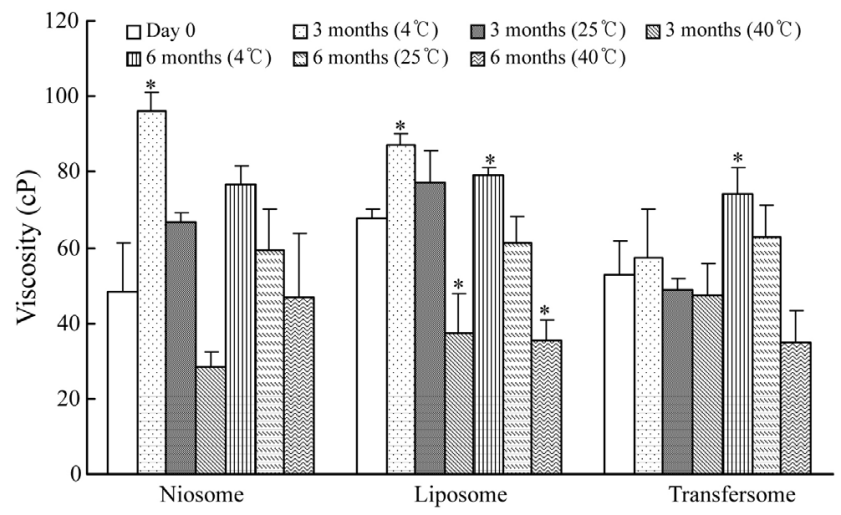

Fig. 4. The viscosity change of vesicles containing $P$. coryfolia extract after production, after storage for 3 months, and after storage for 6 months at 4,25 and $40{ }^{\circ} \mathrm{C}$. Each value represents the mean \pm S.D. $(n=3)$. 
입자 크기 변화를 측정한 결과 Fig. 5에 나타낸 바와 같 이 liposome의 경우 $25^{\circ} \mathrm{C}$ 에서 제조 직후 $196.5 \pm 17.19 \mathrm{~nm}$ 에서 3 개월 후 $227.4 \pm 5.45 \mathrm{~nm}$ 로 약간 증가되었다가 6 개 월 후 $219.7 \pm 25.54 \mathrm{~nm}$ 로 제조 직후 수준으로 회복되었다. $4^{\circ} \mathrm{C}$ 와 $40^{\circ} \mathrm{C}$ 에서는 유의적인 변화가 관찰되지 않았다. niosome 의 경우 $40^{\circ} \mathrm{C}$ 에서 제조 직후 $172.7 \pm 16.41 \mathrm{~nm}$ 에서 3 개월 후 $233.8 \pm 36.85 \mathrm{~nm}, 6$ 개월 후 $297.5 \pm 24.54 \mathrm{~nm}$ 로 약간 상승하는 것으로 나타났다. $4^{\circ} \mathrm{C}$ 와 $25^{\circ} \mathrm{C}$ 에서는 유의적인 변화가 관찰되지 않았다. transfersome의 경우 $25^{\circ} \mathrm{C}$ 와 $40^{\circ} \mathrm{C}$ 에서 제조 직후 $169.9 \pm 7.25 \mathrm{~nm}$ 에서 3 개월 후 $236.9 \pm$ $14.91 \mathrm{~nm}, 327.7 \pm 8.23 \mathrm{~nm}$ 로, 6 개월 후 $209.1 \pm 15.34 \mathrm{~nm}$, $392.1 \pm 23.52 \mathrm{~nm}$ 로 제조 직후에 비해 증가된 상태로 유지 되었다. $4^{\circ} \mathrm{C}$ 에서는 유의적인 변화가 관찰되지 않았다. 이러 한 결과로 보아 liposome, niosome 및 transfersome의 입자 크기는 모든 보관 조건에서 6개월 동안 $160 ~ 300 \mathrm{~nm}$ 사이의 안정한 나노 크기의 입자가 유지되는 것으로 나타났다.

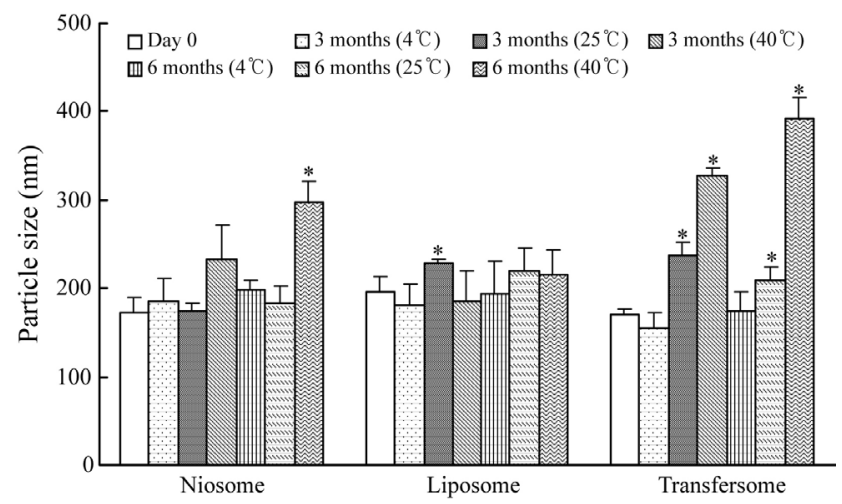

Fig. 5. The particle size of vesicles containing $P$. coryfolia extract after production, after storage for 3 months, and after storage for 6 months at 4,25 and $40^{\circ} \mathrm{C}$. Each value represents the mean \pm S.D. $(n=3)$.

$\mathrm{pH}$ 변화를 측정한 결과 Fig. 6에 나타낸 바와 같이 모든 vesicles에서 $\mathrm{pH}$ 6.1 6.2 사이로 큰 변화 없이 안정한 것으 로 나타났다. 또한, 성상 변화를 관찰한 결과 제조 6 개월 동 안 침강 및 분리와 같은 특이적인 성상변화는 관찰되지 않았 다 (data not shown).

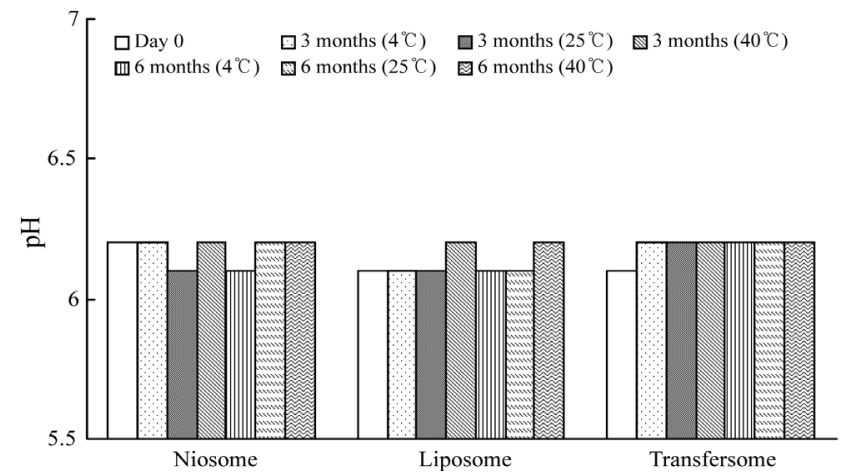

Fig. 6. The $\mathrm{pH}$ change of vesicles containing $P$. coryfolia extract after production, after storage for 3 months, and after storage for 6 months at 4,25 and $40^{\circ} \mathrm{C}$. Each value represents the mean \pm S.D. $(n=3)$.

\section{4. in vitro 투과 및 침적 실험}

보골지 추출물을 liposome, niosome 및 transfersome에 각 각 봉입하여 피부 투과 및 침적 실험 결과를 Fig. 7과 8에 각각 나타내었다.

24시간 동안 마우스 피부를 투과한 바쿠치올의 양을 측정 한 결과 Fig. 7에 나타낸 바와 같이 niosome과 transfersome 에서는 투과되는 바쿠치올의 양이 24시간 이후에 유의성 있게 증가되었으나, liposome에서는 투과되는 바쿠치올의 양이 적은 것으로 나타났다 $(\mathrm{p}<0.05)$. 특히, niosome에서 투과된 바쿠치올의 양은 $360.96 \pm 132.09 \mu \mathrm{g} / \mathrm{mL}$ 으로 적용된 vesicles 중에서 피부 투과율이 가장 높은 것으로 나타났다. 이러한 결과는 소 등이 제시한 특허의 결과와 마찬가지로 소구체의 막의 재질이 피부 각질층의 세포간질 성분과 유사 한 지질로 구성되어 있어 자극이 거의 없고 생체 친화력이 우수하고 유효 성분의 안정화 및 성분 보존 능력이 뛰어나 경피 흡수력이 뛰어나다는 보고와 일치하였다 [20].

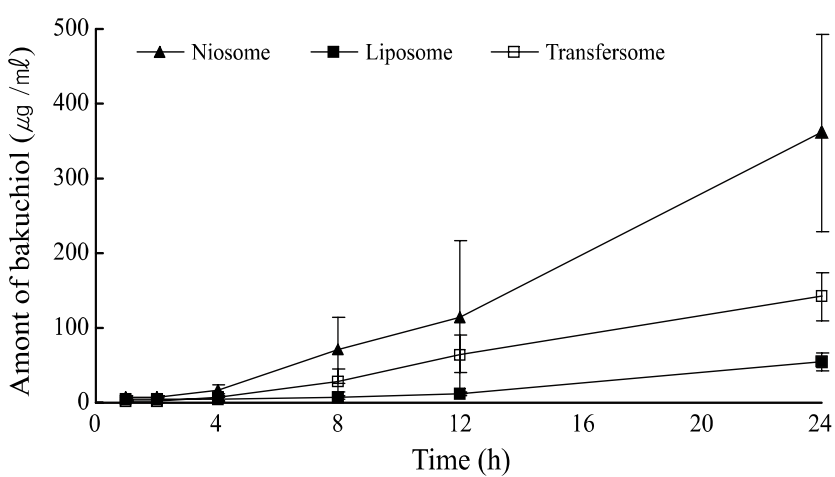

Fig. 7. The skin permeation profiles of bakuchiol across nude mouse skin from vesicles with $P$. coryfolia extract after applying for $24 \mathrm{~h}$. Each value represents the mean \pm S.D. $(n=3)$.

피부 투과 양상에 차이를 보이는 원인을 규명하기 위해 마우스 피부에 도포 24시간 이후 피부를 투과하지 않고 남아 있는 바쿠치올의 양을 각질층과 각질층이 제거된 피부에서 각각 측정하였다. 각질층과 각질층이 제거된 피부에 남아 있는 바쿠치올의 양을 정량한 결과 Fig. 8 에 나타낸 바와 같이 각질층에는 liposome, niosome, transfersome 순으로 많이 남아있는 것으로 나타났고, 각질층이 제거된 피부에 서는 niosome, transfersome, liposome 순으로 나타났다. 이러한 결과로 볼 때 niosome과 transfersome에서는 각질 층에 침적되어 있는 양보다 각질이 제거된 피부에 침적되 거나 피부를 투과하는 양이 더 많은 반면에 liposome의 경우에는 각질층에 머무르는 양이 더 많아 피부를 투과하는 양이 적은 것으로 사료된다. 따라서 원료 자체를 용해하거나 현탁하여 적용하면 피부를 통과하기보다 머무르지만 niosome 과 transfersome과 같은 vesicles을 제조하여 피부에 적용하 면 각질층에 머무르는 양보다 피부를 투과하는 양이 더 많아 지는 것을 알 수 있다. 또한, niosome 또는 transfersome과 같은 생체 이용률 촉진 시스템 (BAES)으로 제형화하여 적용 할 경우 이러한 vesicles 제조시 사용되는 계면활성제와 피부 각질층의 세포간질 성분과 유사한 지질로 구성되어 생체 친 
화력이 우수할 것으로 사료된다. 또한, 유효성분인 바쿠치올 이 피부를 통과하는데 도움을 줄 수 있으므로 즉시적인 효능 을 발휘할 수 있다는 면에서 우수할 것으로 기대되어진다. 그러나 적용된 양에 비해 소량만이 피부에 침적되거나 투과 되므로 이러한 vesicle에 적용하는 유효성분의 농도를 적당 히 조절하여 대부분의 보골지 추출물을 $\mathrm{BAES}$ 안으로 봉입 시키는 것이 바람직할 것으로 사료된다.

(a)

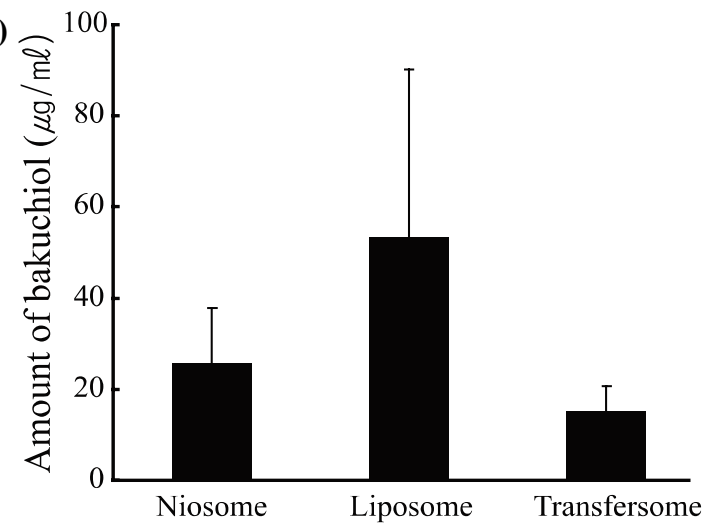

(b)

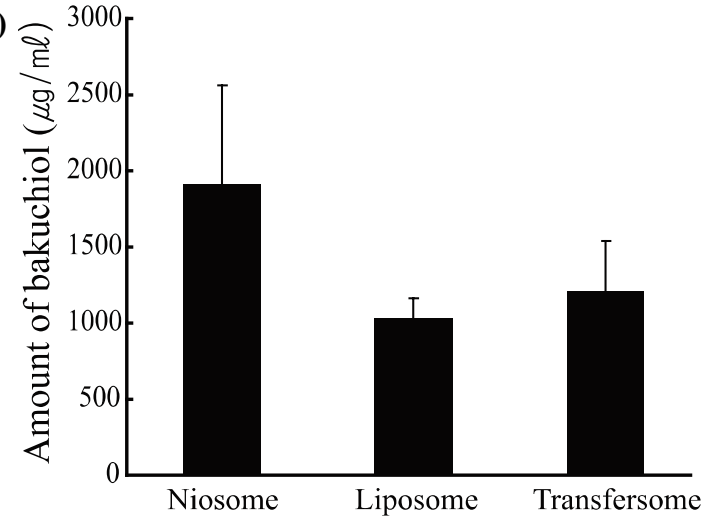

Fig. 8. The amount of bakuchiol deposited in nude mouse skin from vesicles with $P$. coryfolia extract after applying for $24 \mathrm{~h}$ (stratum corneum (a), stripped skin (b)). Each value represents the mean \pm S.D. $(n=3)$.

\section{4. 결론}

보골지 추출물은 항암, 항산화 작용을 가질 뿐만 아니라 광범위한 항균 작용을 가지므로 구강 세척제 등으로 사용되 고 있다. 또한 최근에는 화장품 분야에서 여드름 치료제로 서의 가능성이 검토되고 있는 보골지 추출물 (바쿠치올)의 피부 적용 가능성을 알아보기 위하여 liposome, niosome 및 transfersome에 봉입하여 이들의 안정성을 평가하고 피부 투과에 미치는 영향을 검토하여 다음과 같은 결론을 얻었다.

(1) Liposome, niosome 및 transfersome에 적용할 수 있는 보골지 추출물의 최대 농도는 각각 $24,22,27 \%$ 로 나타 났으며, 모든 vesicles에서 5 10\% 농도가 가장 적절한 것 으로 나타났다.

(2) 보골지 추출물 자체로는 빛과 열에 불안정하였으나 vesicles
에 적용할 경우 안정성이 유지되는 것으로 나타났다.

(3) 24 시간 동안 마우스 피부를 투과한 바쿠치올의 양을 측 정한 결과 niosome과 transfersome에서는 24시간 이후 에 유의성 있게 증가된 것으로 나타난 반면에 liposome 의 경우는 투과되는 바쿠치올의 양이 적은 것으로 나타 났다. 특히, niosome의 경우 투과된 바쿠치올의 양이 $360.96 \pm 132.09 \mu \mathrm{g} / \mathrm{mL}$ 로 적용된 vesicles 중에서 피부 투과율이 가장 높은 것으로 나타났다.

이상의 실험 결과로부터 niosome 및 transfersome과 같 은 생체 이용률 촉진 시스템 (BAES)을 이용할 경우 보골 지 추출물 자체보다 유의성 있게 피부를 투과하는 것으로 나타나 피부 적용 제제로의 개발 가능성을 확인하였다.

\section{References}

1. Oh, S. J. (2008) BAES. Trademark 0115076.

2. Barry, B. W. (2001) Novel mechanism and devices to enable successful transdermal drug delivery. Eur. J. Pharm. Sci. 14: 101-114.

3. Kim, S. (1993) Liposomes as carriers of cancer chemotherapy: current status and future prospects. Drugs. 46: 618-638.

4. Booser, D. and G. Hortobagyi (1994) Anthracycline antibiotics in cancer therapy: focus on drug resistance. Drugs. 47: 223-258.

5. Barber, R. and P. Shek (1993) Pharmaceutical Particulate Carriers. pp. 1-20. In: A. Rolland (eds.). Liposomes as a topical acular drug delivery system. Marcel Dekker, NY, USA.

6. Wong, M. and T. Thompson (1982) Aggregation of dipamitoylphosphatidylcholine vesicles. Biochemistry. 21: 4133-4139.

7. Vora, B., A. J. Khopade, and N. K. Jain (1998) Proniosome based transdermal delivery of levonorgestrel for effective contraception. J. Control. Rel. 54: 149-165.

8. Yoshioka, T., B. Sternberg, and A. T. Florence (1994) Preparation and properties of vesicles (niosomes) of sorbitan monoesters (Span 20, 40, 60 and 80) a sorbitan triester (Span 85). Int. J. Pharm. 105: 1-6.

9. Liu, T., R. Guo, W. Hua, and J. Qui (2007) Structure of hemoglobin in PEG 6000/Tween $80 / \mathrm{Span} 80 / \mathrm{H}_{2} \mathrm{O}$ noisome system. Colloids and surface A: Physicochem. Eng. Aspects. 293: 255-261.

10. Knepp, V. M., R. S. Hinz, F. C. Szoka, and R. H. Guy (1998) Controlled drug release from a novel liposomal delivery system. I. Investigation of transdermal potential. J. Control. Rel. 5: 211-221.

11. Knepp, V. M., F. C. Szoka, and R. H. Guy (1990) Controlled drug release from a novel liposomal delivery system. II. Transdermal delivery characteristics. J. Control. Rel. 12: 25-30.

12. Fang, J. Y., C. H. Hong, W. T. Chiu, and Y. Y. Wang (2001) Effect of liposome and niosomes on skin permeation of enoxacin. Int. J. Pharm. 219: 61-72.

13. Cevc, G. (1992) Liposome Technology. 2nd ed., pp. 1-36. In: G. Gregoriadis (eds.). Lipid Properties as a Basis for the Modelling and Design of Liposome Membranes. CRC-Press, Boca Raton, FL.

14. G. Cevc (1995) Handbook of Physics vol. I. pp. 441-466. In: R. Lipowsky and E. Sackmann (eds.). Material Transport Across Permeability Barriers by Means of Lipid Vesicles. Elsevier 
Science, NY, USA.

15. Kaul, R. (1976) Kinetics of the anti-staphylococcal activity of bakuchiol in vitro. Arzneimittelforschung. 26: 486-489.

16. Katsura, H., R. I. Tsukiyama, A. Suzuki, and M. Kobayashi (2001) In vitro antimicrobial activities of bakuchiol against oral microorganisms. Antimicrob Agents Chemother. 45: 3009-3013.

17. Chaudhuri, R., K. Bojanowski, and F. Marchio (2011) Retinol and retinol-like compounds in skin care. Expression Cosmetique. 227-233.

18. Chaudhuri, R. and F. Marchio (2011) Bakuchiol in the management of acne affected skin. Cosmetics \& Toiletries. 126: 502-510.

19. Lee, S. J. \& Kim, J. H. (1993) Emulsive cosmetic composition of micromultiple lamella small ball structure and preparation thereof. KR Patent 0115076.

20. So, K. S. \& Park, D. L. (1993) Micromultiple sphere composition containing cosmetic component with skin activity and its preparation. KR Patent 0107609.

21. Han, J. W. and J. C. Lim (1999). Study on solubilization of Bunker-C by nonionic surfactans. Applied Chemistry. 3: 324-327.

22. Laia, C. A. T., W. Brown, M. Almgren, and S. M. B. Costa (2000) Light scattering study of water-in-oil AOT microemusions with poly(oxy)ethylene. Langumuir. 16: 465-470.

23. Lehner, D., H. Lindner, and O. Glatter (2000) Determination of the translational and rotational diffusion coefficients of rodlike particles using depolarized dynamic light scattering. Lagumuir. 16: 1689-1695. 